Institute of $\mathbf{F}_{\text {ood and }} \mathbf{A}_{\text {gricultural }} \mathbf{S}_{\text {ciences }}$

\title{
2003 Handbook of Employment Regulations Affecting Florida Farm Employers and Workers: Minimum Wage (Fair Labor Standards Act) [Federal] ${ }^{1}$
}

\author{
Leo C. Polopolus, Michael T. Olexa, Fritz Roka, and Carol Fountain ${ }^{2}$
}

\section{Purpose}

To provide federal minimum hourly wage standards to workers and covered employees.

\section{Who Must Comply}

Any farmer using more than 500 man-days of labor during any calendar quarter of the preceding calendar year (the equivalent of about seven full-time employees working five days a week).

If the employer did not employ more than 500 man-days of agricultural labor in any quarter of the preceding calendar year, his or her agricultural employees are exempt from the minimum wage provisions of the Act for the entire following calendar year. Conversely, if the employer used more than 500 man-days of farm labor in any calendar quarter of a year, coverage extends to the entire following calendar year even if the employer does not use 500 man-days of labor in any quarter of the second year.

Employees are excluded from the minimum wage and overtime requirements of the law as well as the 500 man-day test if such employee is the parent, spouse, child, or other member of his or her employer's immediate family.

The following employees are also exempt from the minimum wage and overtime requirements of the law, but their man-days of work must be counted toward the 500 man-day test:

- Employees who are paid on a piece-rate basis, AND were employed in agriculture as hand-harvest laborers fewer than thirteen weeks

1. This is EDIS document FE407, a publication of the Department of Food and Resource Economics, Florida Cooperative Extension Service, Institute of Food and Agricultural Sciences, University of Florida, Gainesville, FL. First published February 1992 as Circular 1043 Florida Cooperative Extension Service. Revised November 1997 and December 2002 as Circular 1200. Please visit the EDIS website at http://edis.ifas.ufl.edu.

2. Leo C. Polopolus, Professor Emeritus, Department of Food and Resource Economics, University of Florida, Gainesville, FL; Michael T. Olexa, Professor, Department of Food and Resource Economics, University of Florida, Gainesville, FL; Fritz Roka, Associate Professor, Department of Food and Resource Economics, Southwest Florida Research and Education Center, Immokalee, FL; and Carol Fountain, Assistant Editor, Department of Food and Resource Economics, University of Florida, Gainesville, FL; Florida Cooperative Extension Service, Institute of Food and Agricultural Sciences, University of Florida, Gainesville, FL.

This document is designed to provide accurate, current, and authoritative information on the subject. However, since the laws, administrative rulings, and court decisions on which it is based are subject to constant revision, portions of this publication could become outdated at any time. This publication is distributed with the understanding that the authors are not engaged in rendering legal or other professional advice, and the information contained herein should not be regarded as a substitute for professional advice. For these reasons, the utilization of these materials by any person constitutes an agreement to hold harmless the authors, the Institute of Food and Agricultural Sciences, and the University of Florida for any liability claims, damages, or expenses that may be incurred by any person as a result of reference to or reliance on the information contained in this publication.

The Institute of Food and Agricultural Sciences is an equal opportunity/affirmative action employer authorized to provide research, educational information and other services only to individuals and institutions that function without regard to race, color, sex, age, handicap, or national origin. For information on obtaining other extension publications, contact your county Cooperative Extension Service office. Florida Cooperative Extension Service/Institute of Food and Agricultural Sciences/University of Florida/Christine Taylor Waddill, Dean. 
in the previous year AND commute to work daily (non-migrants).

- An employee in agriculture whose employer did not, during any calendar quarter of the preceding calendar year, use more than 500 man-days of agricultural labor.

- Any agricultural employee sixteen-years- old or younger who is:

- Employed as a hand-harvest laborer.

- Paid on piece-rate basis in an operation which is customarily and generally recognized as paid for on piece-rate basis in the region.

- Employed on the same farm as his or her parent(s) or person(s) standing in place of his or her parent(s).

- Paid at the same piece rate as employees over age sixteen on the same farm.

- Employees principally engaged in livestock range production who must be available at all hours to care for such livestock. (The judicial application of this exemption does not turn on the characteristics of land use for grazing but on conditions under which the employees perform their duties. The exemption is applicable only if the method of operation is such that the computation of hours worked caring for the stock would be extremely difficult).

\section{Minimum Wage}

Employers must, if covered, pay at least the minimum wage to all covered employees. Beginning September 1, 1997, the minimum wage increased to $\$ 5.15$ an hour.

\section{Opportunity Wage}

Employers may pay entry wages of not less than $\$ 4.25$ an hour to workers less than twenty years of age, but only for the first ninety consecutive calendar days (not days of work). Employers, however, cannot take action to displace regular employees to hire workers under age twenty at the opportunity wage.

\section{Record-Keeping}

Payroll records must be maintained for at least three years for each employee, including family members of employees.

This three-year requirement for records preservation includes any contracts, agreements, or memoranda concerning employment; and any collective bargaining agreements. In addition, sales and purchase records are to be maintained for three years.

The following records must be retained for a two-year period:

- Basic employment and earnings records such as time cards or time sheets.

- Wage rate tables or schedules.

- Order, shipping, and billing records.

- Itemized support for additions to and deductions from wages.

These records should include:

- Full name of employee (same name as used for Social Security purposes).

- Complete home address, including zip code.

- Sex and occupation in which employed.

- Identification of employees who are:

- Members of an employer's immediate family.

- Hand-harvest workers paid on a piece-rate basis.

- Employees principally engaged in range livestock production.

- The number of man-days worked each week or month (a man-day is any day during which an employee does agricultural work for one hour or more).

- Time of day and day of week on which work week begins. 
- Basis on which wages are paid (i.e., rate per hour, rate per day, or rate per piece work).

- Hours worked each work day and total hours worked each work week.

- Total daily or weekly earnings, depending on the applicable pay period.

- Total additions to or deductions from wages with an explanation of each.

- Total wages paid each pay period together with proof of payment to individual workers, including cash advances or other deductions.

- Date of payment and pay period covered by payment.

Have on file a statement from each exempt piece-rate employee showing the number of weeks employed in agriculture during the preceding year.

Have on file the date of birth and the parents' names for each exempt minor (under age sixteen) paid on a piece-rate basis.

Maintain a file showing the full name, present and permanent address, and date of birth of any minor under age eighteen who works when school is in session or works in a hazardous occupation.

Display the official poster "Notice to Employees" where employees can see it. This poster contains basic information on minimum wages.

\section{Overtime Exemption}

Employees employed in agriculture as defined by the Fair Labor Standards Act are exempt from overtime. In general, under the primary definition of agriculture, if the employee is engaged in cultivating the soil; or growing or harvesting crops; or raising livestock, bees, fur-bearing animals, or poultry, he or she is engaged in agriculture and exempt from overtime. Under the secondary definition of agriculture, any practices performed, other than those listed under the primary definition such as office work, shipping, warehousing, transporting, sales, etc., are exempt only if performed by employees of the farmer with respect to products grown by their employer or, if performed on a farm, as an incident to and in conjunction with products grown on the particular farm on which they are working. Performance in a week of any work that is not exempt under the primary or secondary definition will cause the employee to be subject to overtime for that week.

Because some employees of Florida agricultural employers handle or otherwise work on products not grown by their employer or do work not within the definition of agriculture as outlined above, the employer should seek professional legal counsel or advice from the local U.S. Department of Labor, Wage and Hour office concerning specifics of the overtime exemption.

However, workers (not employed by the farmer on whose farm they are working) who work solely on a farm where their work relates only to fruits, vegetables, or nursery products grown on that farm are exempt from overtime.

Citrus grove caretakers who have full responsibility for growing citrus in groves owned by others are considered to be farmers with respect to the crop they are growing.

\section{Overtime Exemption for Agricultural Transportation}

The complete overtime exemption is available for any employee engaged in the transportation or preparation for transportation of fruits and vegetables to the first place of processing or first marketing within the same state (even when performed by a non-farmer). However, mechanics and office workers of a harvester or purchaser are not exempt from overtime.

This overtime exemption also applies to any employee transporting farmworkers to be employed in the harvesting of fruits or vegetables between any place in the same state and the farm (whether or not performed by the farmer).

\section{Certain Deductions Possible}

Employers may deduct the cost of certain items from farmworker wages. However, care should be exercised because deductions of certain items cannot reduce wages below the minimum wage. 
Deductions that may lawfully reduce wage level below the current minimum wage are:

- Taxes required by law (e.g., Social Security, Medicare, and withholding tax).

- Third Party deductions authorized by the employee (e.g., union dues, savings bonds, merchant accounts, insurance premiums, churches, and charitable organizations) so long as the employer receives no profit or benefit directly or indirectly.

- Salary advances exclusive of interest charges. Receipts must be obtained and retained.

- Housing and meals not exceeding the lesser of actual costs or fair rental value and meeting a number of specified conditions dealing with profit and rate of return on investment (29 C.F.R., Part 531). Housing facilities must be maintained for the benefit of employees, occupancy must not be mandatory, and costs cannot include depreciation when the facilities have been fully depreciated. Recent rulings by the Department of Labor indicate some migrant housing may have no fair rental value. If you provide and charge farmworkers for housing that can only be used by migrant workers and, thus, has no fair rental value, this rental charge cannot reduce their wages below the current minimum wage.

Currently, a deduction that may not lawfully reduce wage level below the current minimum wage is transportation advances (the legality of this deduction is being appealed in the courts). This policy applies where agricultural employers provide daily transportation to assure a sufficient number of workers. However, when the following three factors are all present, agricultural employers may deduct from workers' wages the lesser of reasonable costs or fair value of such transportation regardless of whether such deductions will decrease workers' wages below the minimum wage:

- The workers must know the location of their work site.
- Alternative transportation sources (i.e., personal automobile or car-pool) must be readily available.

- The workers are not required to use the employer's transportation.

- Charges for contractor's (crew leader) services.

- Charges for "Tools of the Trade and Other Materials Incidental to Carrying on the Employer's Business."

\section{Retaliation Policy}

The minimum wage law forbids any person to discharge or in any other manner discriminate against any employee because he or she has filed any complaint or instituted or caused to be instituted any proceeding under or related to this law.

\section{Posting Requirements}

The official poster of the U.S. Department of Labor, "Notice to Employees" must be displayed where employees can see it. It must also be securely affixed. The following notation may be added: "Overtime provisions not applicable to employees employed in agriculture."

Failure to post is considered a violation of the minimum wage law.

\section{Enforcement}

The U.S. Department of Labor's Wage and Hour Division enforces the minimum wage law (Fair Labor Standards Act).

Following an inspection by the Department of Labor, an employer can be ordered to pay back wages and liquidated damages. Civil money penalties for violations of minimum wage law can be:

- Cvil money penalties up to $\$ 1,000$ per violation, per employee for willful or repeated violations of minimum wage and/or overtime pay requirements.

- Civil lawsuits by the U.S. Department of Labor. 
- Civil lawsuits by employees.

- Criminal indictments and penalties for violations under the Act by Department of Labor.

\section{Responsible Agency}

\section{Regional Office}

U.S. Department of Labor

ESA Wage and Hour Regional Office

61 Forsyth Street, Room 6M12

Atlanta, GA 30303

(404) 562-2092

http://www.doleta.gov/regions/reg03

\section{Area Offices}

(See EDIS document FE391, Child Labor [Federal].) 